\title{
Structure of bird communities in eucalyptus plantations: nestedness as a pattern of species distribution
}

\author{
L. I. Jacoboski ${ }^{1 *}$, A. de Mendonça-Lima ${ }^{1+}$ and S. M. Hartz ${ }^{1}$ \\ ${ }^{1}$ Programa de Pós-graduação em Ecologia, Laboratório de Ecologia de Populações e Comunidades, Universidade Federal \\ do Rio Grande do Sul - UFRGS, Av. Bento Gonçalves, 9500, CEP 91501-970, Porto Alegre, RS, Brazil \\ *e-mail: lucilene.jacoboski@yahoo.com.br \\ †n memoriam
}

Received: September 8, 2014 - Accepted: June 2, 2015 - Distributed: August 31, 2016

(With 3 figures)

\begin{abstract}
Replacement of native habitats by tree plantations has increased dramatically in Brazil, resulting in loss of structural components for birds, such as appropriate substrates for foraging and nesting. Tree plantations can also reduce faunal richness and change the composition of bird species. This study evaluated the structure of avian communities in eucalyptus plantations of different ages and in a native forest. We classified species as habitat specialists or generalists, and assessed if the species found in eucalyptus plantations are a subset of the species that occur in the native forest. Forty-one sampling sites were evaluated, with three point counts each, in a native forest and in eucalyptus plantations of four different ages. A total of 71 bird species were identified. Species richness and abundance were higher in the native forest, reflecting the greater heterogeneity of the habitat. The composition of bird species also differed between the native forest and plantations. The species recorded in the plantations represented a subset of the species of the native forest, with a predominance of generalist species. These species are more tolerant of habitat changes and are able to use the plantations. The commercial plantations studied here can serve as a main or occasional habitat for these generalists, especially for those that are semi-dependent on edge and forest. The bird species most affected by silviculture are those that are typical of open grasslands, and those that are highly dependent on well-preserved forests.
\end{abstract}

Keywords: avian fauna, subsets, eucalyptus plantations, native forest.

\section{Estrutura de comunidades de aves em plantios de eucalipto: aninhamento como padrão de distribuição de espécies}

\begin{abstract}
Resumo
A substituição de ambientes nativos pela silvicultura está se tornando uma prática cada vez mais comum no Brasil, resultando na perda de componentes estruturais para as espécies de aves, como substratos específicos de forrageamento e nidificação. Esta prática pode reduzir a riqueza e alterar a composição das comunidades de aves. O objetivo deste estudo foi avaliar diferenças na estrutura de comunidades de aves em plantios de eucalipto de diferentes idades e em floresta nativa. Além disso, teve como objetivo classificar espécies em especialistas ou generalistas de habitat e avaliar se espécies encontradas nos plantios de eucalipto representam subconjuntos da floresta nativa. Quarenta e um sítios de amostragem foram avaliados, com três pontos de contagem cada, em uma floresta nativa e em plantios de eucalipto de quatro diferentes idades. Foi identificado um total de 71 espécies de aves. A riqueza de espécies e abundância foram maiores na floresta nativa refletindo a maior heterogeneidade desse habitat. A composição de espécies de aves também diferiu entre a floresta nativa e os plantios. As espécies registradas nos plantios representam um subconjunto das espécies da floresta nativa, o que é explicado pelo predomínio das espécies generalistas. Essas espécies são mais tolerantes às alterações de habitat e são capazes de utilizar os plantios. Nesse sentido, plantios comerciais estudados aqui podem servir como habitat para essas espécies seja de forma principal ou ocasional, especialmente para aquelas espécies de borda e semi-dependentes florestais. Por conseguinte, as espécies de aves mais prejudicadas pela silvicultura são espécies associadas à habitats campestres e aquelas que apresentam alta dependência a florestas bem preservadas.
\end{abstract}

Palavras-chave: avifauna, subconjuntos, plantios eucalipto, floresta nativa. 


\section{Introduction}

Changes in land use have resulted in habitat loss worldwide, modifying the rates and intensity of many ecological processes that are essential to maintain ecosystem integrity (Lambeck, 1997). In the tropics, native and exotic tree species are planted for lumber and pulpwood production (FAO, 2012) and, in some cases, to compensate for loss of the native forest (Farwig et al., 2008). Conversion of native forests to tree plantations composed of exotic species is contrary to the principles of biodiversity conservation (Brockerhoff et al., 2008). The ecological functions of native forests cannot be completely replaced in plantations (Volpato et al., 2010). Thus, in plantations, bird diversity is lower and community composition is different from native forests (Marsden et al., 2001; Farwig et al., 2008). Conversion of native vegetation to other land uses has been detrimental to many native bird species in a variety of ecosystems (Zurita et al., 2006; Deconchat et al., 2009). Therefore, species diversity and community composition in tree plantations are of particular interest for the development of conservation strategies.

Alterations in the landscape due to tree plantations can cause more or less severe effects, depending on the type of management employed, such as removal of understory vegetation. Another important factor to consider is the surrounding landscape, which can also influence bird species composition (Lindenmayer et al., 2003; Farwig et al., 2008). However, bird species are not equally vulnerable to habitat changes, as species specialization (e.g. dependence on native forests) is often associated with an increased risk of extinction (Sekercioglu et al., 2004).

Simplification of the vegetation structure and composition is inherent in plantations (Zurita et al., 2006; Filloy et al., 2010). Vegetation structure (e.g. richness, stratification) is an important factor affecting the composition of bird communities (Hobbs et al., 2003; Gabriel, 2009; Filloy et al., 2010; Volpato et al., 2010; Mendonça-Lima, 2012). In silviculture areas, avian communities may consist mainly of habitat generalists, i.e., species that use a relatively wide set of habitat resources (Colles et al., 2009), and species associated with forest edges and open areas.

In spite of the differences between plantations and native forests, species coexistence is expected to occur, as forest species tend to colonize plantations (Mendonça-Lima, 2012). Thus, the species distribution in tree plantations can result in nested subsets. Nestedness is defined by several investigators as the degree to which species-poor communities are subsets of species-rich communities (Patterson and Atmar, 1986; Wright et al., 1998). Nestedness was first assumed to depend entirely on species extinction and area size (Patterson and Atmar, 1986). Later studies indicated that it can also depend on colonization and habitat nestedness (Patterson, 1990; Ulrich et al., 2009). In recent years, nestedness analysis has been widely used as an ecological tool to describe patterns of species occurrence and their fundamental mechanisms (Ulrich et al., 2009). Hence, evaluation of nestedness of bird species in eucalyptus plantations of different ages in relation to native forests can aid in the understanding of species distribution patterns in different habitats.

In this study, we evaluated the distribution and nestedness of the bird assemblage in eucalyptus plantations in relation to native forest. The following hypotheses were tested. 1) Eucalyptus plantation areas would show lower richness and abundance, and a different composition of bird species compared to native forest areas. 2) More habitat generalists would be expected to occur in eucalyptus plantations. 3) The avian fauna found in eucalyptus plantation areas would show a nested distribution pattern in relation to the native forest.

\section{Material and Methods}

\subsection{Study area}

This study was conducted in the Horto Florestal Barba Negra (HFBN), owned by the company CMPC Celulose Riograndense. The HFBN is a silviculture farm for pulpwood production. This area is located in Barra do Ribeiro municipality, between $30^{\circ} 27^{\prime} 55$ and $30^{\circ} 26^{\prime} 32 \mathrm{~S}$, and $051^{\circ} 16^{\prime} 04$ and $051^{\circ} 05^{\prime} 44 \mathrm{~W}$, about $60 \mathrm{~km}$ from Porto Alegre, Rio Grande do Sul State, Brazil. The HFBN area is a peninsula bordered on the north and northeast by Guaíba Lake, on the south and southeast by Patos Lagoon, and the west by cropland and livestock pastures (Sydow, 2010).

The regional climate in is predominantly humid subtropical (Köppen's Cfa). The mean annual temperature is $19.3^{\circ} \mathrm{C}$ and the annual precipitation is about $1322 \mathrm{~mm}$, according to Köppen's climate classification (Moreno, 1961).

The total area of HFBN is 10,600 ha, with 2,400 ha of permanent preservation area (PPA), and a eucalyptus plantation on the remaining 8,200 ha. In Brazil, PPAs are legally protected areas. The sampling in the native forest was conducted on Formiga Hill, which is located in the PPA. The vegetation of the HFBN region consists of "restinga", a coastal sand pioneer formation, close to the coastal plain; and forest vegetation, which increases with the distance from the coast. The forest vegetation consists of Semideciduous Atlantic Forest, comprising species of Deciduous Forest and Dense Ombrophilous Forest (Leite, 2002).

In the HFBN, the eucalyptus stands are planted in a mosaic (plantations of several ages), to avoid large areas with same-aged trees. The trees are cut about seven years after planting, and the understory vegetation is not managed.

\subsection{Experimental design}

Sampling was conducted in the commercial eucalyptus plantations and in the native restinga forest. Eucalyptus plantations were classified in four categories according to their age. The following five groups were established for sampling. Treatment 1 (T1) - plantations up to 3 years old. Treatment 2 (T2) - plantations from 3 to 7 years. Treatment 3 (T3) - plantations from 7 to 12 years. Treatment 4 (T4) - plantations from 14 to 25 years. Treatment 5 - sampling sites in the native forest (NF). In each group, 
10 sampling sites were established. For the treatments, each site consisted of a plantation area. These sites were designated a priori with the criterion that there was no contiguity between plantations. However, sites in the native forest were established in only one area, on four different paths. This was necessary since other areas in the HFBN were too small to use this method.

At each site, three points were established, totaling 150 points where bird species were sampled. The point-count method was used, with the observer remaining for 10 minutes at each point. Each point count had a fixed radius of $50 \mathrm{~m}$, as according to Anjos et al. (2011), most species can only be heard up to $40-50 \mathrm{~m}$ from the observer. During this period, every bird species seen or heard was recorded. A minimum distance of $200 \mathrm{~m}$ was established between points, avoiding plantation and forest edges. The counts started 30 minutes after sunrise and lasted about 3 hours. Each morning, two sites of two groups were sampled. Each treatment was sampled during different periods in the 3 hours of sampling. Sites were sampled only once. Sampling was conducted from October through December 2012. Bird species nomenclature and classification follows the Annotated checklist of the birds of Brazil by the Brazilian Ornithological Records Committee (Piacentini et al., 2015).

\subsection{Data analysis}

The sampling units used for analysis were the sites (plantation areas), and for the native forest, each site consisted of three point counts combined. Thus, the records from the three point counts in each site were treated as one sampling unit, since the aim of the study was to evaluate possible differences between treatments, and not between point counts.

Bird species richness was rarefied to standardize the samples, because of differences in number of individuals (Gotelli and Colwell, 2001), using the software PAST (Hammer et al., 2001). A species abundance index was calculated, dividing the number of contacts of each species by the total number of point counts. Then, analysis of variance (ANOVA) with randomization was used (Pillar and Orlóci, 1996) to evaluate differences in rarefied richness and also to compare bird species abundance among treatments. In order to assess differences in bird species composition between treatments, a multivariate analysis of variance (MANOVA) was used, with randomization. When analyses of variance indicated significant differences between treatments, contrast analyses were performed for pairwise comparisons (Pillar and Orlóci, 1996). A principal coordinates analysis (PCoA) was used as an exploratory analysis to evaluate the bird species composition in relation to the treatments. All analyses of variance and the ordination used Euclidean distances, and were performed using the software MULTIV 2.63 (Pillar, 2006).

To determine habitat specificity of species, bird species were classified according to a method developed to determine habitat specialists and generalists (Chazdon et al., 2011). This method uses a multinomial model based on a species' relative abundance in two environments, and classifies species into one of the following categories: (1) generalist; (2) habitat "A" specialist; (3) habitat "B" specialist; and (4) too rare to classify (Chazdon et al., 2011). The major advantage of this method is the classification of habitat specialists and generalists without exclusion of rare species a priori, and the ability to distinguish habitat generalists from species that are simply too rare to classify (Chazdon et al., 2011). As recommended by Chazdon et al. (2011), a $K$ specialization threshold of 0.667 was defined, with a $p$ level of 0.005 (suitable for assessing the overall pattern). Species were classified as habitat specialists or generalists with the software CLAM (Chao and Lin, 2011). As this software aims to compare only two different environments, species recorded in eucalyptus plantations of different ages were quantified in only one group by their relative abundance, i.e., we evaluated plantations $\mathrm{x}$ native forest.

To evaluate if species composition in the plantations is a subset of species that occur in the native forest, we conducted a nestedness analysis with the software NODF (Almeida-Neto and Ulrich, 2011). Nestedness was calculated separately for each plantation age in relation to the native forest. Then, an overall nestedness was calculated (comparing all the treatments). For overall nestedness, 10 presence/absence matrices were generated, consisting of a set with all treatments. For each observed matrix, two null models were generated, with 1,000 permutations, using the software NODF (Almeida-Neto and Ulrich, 2011). The first null model maintained the number of presences, but assigned these anywhere (rows equiprobable and columns equiprobable). The second null model maintained species frequencies, but area frequencies were not preserved (rows fixed and columns equiprobable). Then, nestedness was calculated for each observed matrix and for 10 random matrices generated by each null model to obtain two sets of 10 pairs of nestedness values (the observed value and its respective value in each null model). A paired t-test was performed for each null model to test if the observed nestedness was larger than expected (Schneck et al., 2011), using the R environment (R Development Core Team, 2012).

\section{Results}

A total of 71 species were identified in the treatments (Table 1). Of these, 56 species occurred in the native forest (NF), 41 in plantations up to 3 years old (T1), 33 in plantations from 3 to 7 years (T2), 30 in plantations from 7 to 12 years (T3), and 30 in plantations from 14 to 25 years (T4). Rarefied richness and abundance were higher in the native forest, differing significantly from the eucalyptus plantations $(\mathrm{Q}=750.09$; $p=0.0001, \mathrm{Q}=3765.1 ; p=0.0001$, respectively); between plantations, the results were similar (Figure 1a-b).

In relation to species composition, the MANOVA indicated significant differences between the native forest and the four treatments with eucalyptus plantations $(\mathrm{Q}=72.88 ; p=0.0001)$. The exploratory analysis (PCoA) showed the species as distributed in three groups. The first 
Table 1. Classification of bird species recorded in the eucalyptus plantations and in the native forest, with total abundance of species in each treatment. Plantations up to 3 years old (T1), plantations from 3 to 7 years (T2), plantations from 7 to 12 years (T3), plantations from 14 to 25 years (T4) and native forest (NF). Nomenclature follows Piacentini et al. (2015).

\begin{tabular}{|c|c|c|c|c|c|c|}
\hline Category & Species & T1 & T2 & T3 & T4 & NF \\
\hline \multirow{20}{*}{ Generalists } & Leptotila verreauxi & 11 & 4 & 6 & 6 & 15 \\
\hline & Leptotila rufaxilla & 5 & 3 & 1 & 0 & 7 \\
\hline & Pyrrhura frontalis & 2 & 0 & 4 & 3 & 10 \\
\hline & Myiopsitta monachus & 5 & 5 & 3 & 0 & 6 \\
\hline & Thamnophilus caerulescens & 3 & 4 & 2 & 6 & 14 \\
\hline & Conopophaga lineata & 2 & 4 & 6 & 3 & 10 \\
\hline & Pachyramphus polychopterus & 2 & 2 & 8 & 0 & 7 \\
\hline & Poecilotriccus plumbeiceps & 0 & 4 & 2 & 0 & 12 \\
\hline & Camptostoma obsoletum & 6 & 4 & 8 & 1 & 7 \\
\hline & Elaenia mesoleuca & 0 & 0 & 0 & 2 & 11 \\
\hline & Serpophaga subcristata & 2 & 5 & 8 & 5 & 8 \\
\hline & Megarynchus pitangua & 2 & 0 & 5 & 0 & 8 \\
\hline & Cyclarhis gujanensis & 10 & 15 & 20 & 19 & 12 \\
\hline & Turdus rufiventris & 12 & 14 & 15 & 9 & 10 \\
\hline & Turdus amaurochalinus & 9 & 3 & 1 & 2 & 25 \\
\hline & Saltator similis & 11 & 8 & 3 & 9 & 16 \\
\hline & Tangara preciosa & 2 & 5 & 1 & 4 & 6 \\
\hline & Setophaga pitiayumi & 5 & 16 & 11 & 15 & 26 \\
\hline & Basileuterus culicivorus & 2 & 11 & 16 & 5 & 17 \\
\hline & Myiothlypis leucoblephara & 0 & 14 & 2 & 12 & 20 \\
\hline \multirow{3}{*}{ Eucalyptus opportunists } & Pitangus sulphuratus & 7 & 5 & 10 & 7 & 2 \\
\hline & Troglodytes musculus & 20 & 22 & 23 & 20 & 11 \\
\hline & Zonotrichia capensis & 27 & 20 & 12 & 13 & 2 \\
\hline \multirow{4}{*}{ Native-forest specialists } & Patagioenas picazuro & 2 & 1 & 1 & 1 & 21 \\
\hline & Chiroxiphia caudata & 0 & 0 & 0 & 0 & 10 \\
\hline & Turdus albicollis & 0 & 0 & 0 & 0 & 22 \\
\hline & Coereba flaveola & 1 & 0 & 0 & 0 & 12 \\
\hline \multirow{12}{*}{ Too rare to classify } & Crypturellus obsoletus & 1 & 3 & 0 & 0 & 2 \\
\hline & Geotrygon montana & 0 & 0 & 0 & 0 & 2 \\
\hline & Crotophaga ani & 2 & 0 & 0 & 0 & 0 \\
\hline & Guira guira & 2 & 2 & 0 & 1 & 0 \\
\hline & Hydropsalis torquata & 1 & 0 & 0 & 0 & 0 \\
\hline & Stephanoxis lalandi & 0 & 0 & 0 & 0 & 6 \\
\hline & Chlorostilbon lucidus & 0 & 0 & 1 & 0 & 0 \\
\hline & Thalurania glaucopis & 0 & 0 & 0 & 0 & 2 \\
\hline & Hylocharis chrysura & 0 & 0 & 0 & 0 & 1 \\
\hline & Leucochloris albicollis & 1 & 1 & 0 & 2 & 1 \\
\hline & Trogon surrucura & 0 & 0 & 0 & 0 & 4 \\
\hline & Colaptes melanochloros & 0 & 0 & 0 & 0 & 3 \\
\hline \multirow{11}{*}{ Too rare to classify } & Sclerurus scansor & 0 & 0 & 0 & 0 & 2 \\
\hline & Sittasomus griseicapillus & 0 & 0 & 0 & 0 & 2 \\
\hline & Dendrocolaptes platyrostris & 0 & 0 & 0 & 0 & 1 \\
\hline & Syndactyla rufosuperciliata & 0 & 0 & 0 & 0 & 7 \\
\hline & Cranioleuca obsoleta & 0 & 0 & 0 & 0 & 3 \\
\hline & Carpornis cucullata & 0 & 0 & 0 & 0 & 1 \\
\hline & Phylloscartes ventralis & 0 & 2 & 0 & 2 & 2 \\
\hline & Tolmomyias sulphurescens & 4 & 2 & 0 & 3 & 2 \\
\hline & Elaenia flavogaster & 0 & 0 & 0 & 0 & 4 \\
\hline & Elaenia $\mathrm{sp}$ & 2 & 6 & 0 & 2 & 3 \\
\hline & Elaenia $\mathrm{sp}$ & 0 & 0 & 0 & 2 & 0 \\
\hline
\end{tabular}


Table 1. Continued...

\begin{tabular}{|c|c|c|c|c|c|c|}
\hline Category & Species & T1 & $\mathbf{T 2}$ & T3 & T4 & NF \\
\hline \multirow{23}{*}{ Too rare to classify } & Myiopagis viridicata & 0 & 0 & 0 & 0 & 2 \\
\hline & Myiarchus swainsoni & 4 & 0 & 2 & 1 & 2 \\
\hline & Myiodynastes maculatus & 0 & 0 & 8 & 7 & 2 \\
\hline & Tyrannus savanna & 2 & 0 & 0 & 0 & 0 \\
\hline & Tyrannus melancholicus & 2 & 0 & 0 & 0 & 0 \\
\hline & Empidonomus varius & 0 & 0 & 2 & 0 & 0 \\
\hline & Myiophobus fasciatus & 0 & 0 & 0 & 0 & 2 \\
\hline & Lathrotriccus euleri & 0 & 0 & 0 & 0 & 2 \\
\hline & Vireo olivaceus & 0 & 0 & 0 & 0 & 6 \\
\hline & Turdus leucomelas & 0 & 0 & 3 & 2 & 2 \\
\hline & Turdus subalaris & 0 & 0 & 0 & 2 & 1 \\
\hline & Tachyphonus coronatus & 0 & 0 & 0 & 0 & 4 \\
\hline & Lanio cucullatus & 0 & 0 & 2 & 0 & 0 \\
\hline & Tangara sayaca & 0 & 0 & 8 & 5 & 2 \\
\hline & Ammodramus humeralis & 2 & 2 & 0 & 0 & 0 \\
\hline & Sicalis flaveola & 2 & 1 & 0 & 0 & 0 \\
\hline & Sicalis luteola & 2 & 2 & 0 & 0 & 0 \\
\hline & Volatinia jacarina & 5 & 4 & 0 & 0 & 0 \\
\hline & Cyanoloxia brissonii & 3 & 4 & 0 & 0 & 4 \\
\hline & Geothlypis aequinoctialis & 2 & 3 & 0 & 0 & 2 \\
\hline & Icterus pyrrhopterus & 1 & 0 & 0 & 0 & 0 \\
\hline & Molothrus bonariensis & 2 & 0 & 0 & 0 & 0 \\
\hline & Euphonia chlorotica & 0 & 0 & 0 & 0 & 2 \\
\hline
\end{tabular}
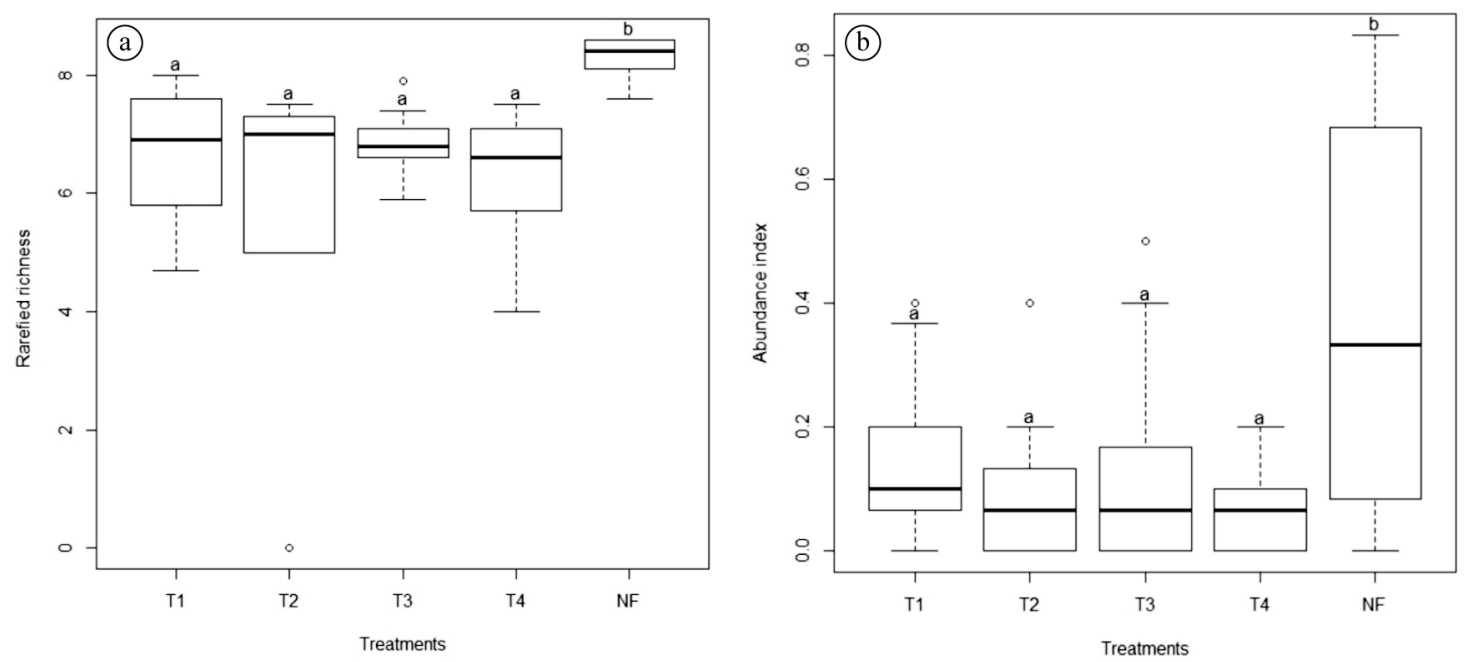

Figure 1. Box plots for rarefied richness values (a) and bird species abundance index (b) showing the difference between the treatments, with their maximum and minimum values and standard error. Caption: T1 (eucalyptus plantations up to 3 years old), T2 (eucalyptus plantations from 3 to 7 years), T3 (eucalyptus plantations from 7 to 12 years), T4 (eucalyptus plantations from 14 to 25 years), NF (native forest). Different letters indicate significant differences between treatments.

group comprised species that are characteristic of initial plantations (T1). The second group consisted of species associated with intermediate and old plantations (T2, T3, T4). The third group was formed by species that are characteristic of the native forest (Figure 2).
In relation to bird species classification, 46 of the 73 species were considered too rare to classify (about 60\%). Twenty species were classified as generalists. Pitangus sulphuratus (Linnaeus, 1766), Zonotrichia capensis (Statius Muller, 1776) and Troglodytes musculus (Naumann, 1823) 


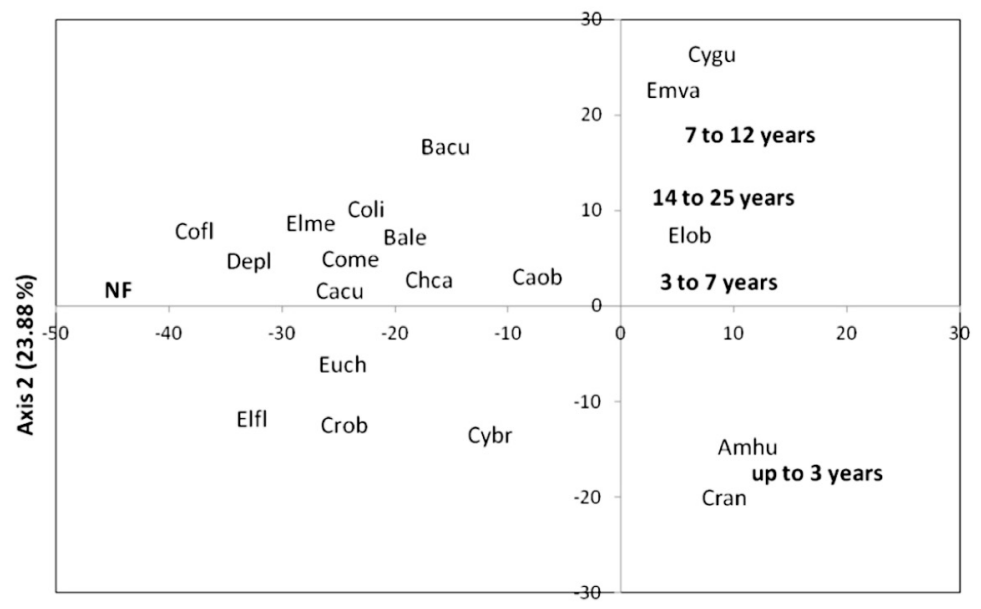

Axis 1 (46.23\%)

Figure 2. Ordination diagram by Principal Coordinates Analysis of the first and second axes, showing the array of the areas (bold) and bird species distribution. Captions: NF (native forest), up to 3 years old (T1), 3 to 7 years (T2), 7 to 12 years (T3), and 14 to 25 years (T4) (eucalyptus plantations according to their ages), Cran (Crotophaga ani), Amhu (Ammodramus humeralis), Turu (Turdus rufiventris), Emva (Empidonomus varius), Cygu (Cyclarhis gujanensis), Cybr (Cyanoloxia brissonii), Caob (Camptostoma obsoletum), Bacu (Basileuterus culicivorus), Coli (Conopophaga lineata), Bale (Basileuterus leucoblepharus), Chca (Chiroxiphia caudata), Elme (Elaenia mesoleuca), Come (Colaptes melanochloros), Cacu (Carpornis cucullata), Cofl (Coereba flaveola), Depl (Dendrocolaptes platyrostris), Euch (Euphonia chlorotica), Elfl (Elaenia flavogaster), Crob (Crypturellus obsoletus).

were classified as eucalyptus-associated. Patagioenas picazuro (Temminck, 1813), Chiroxiphia caudata (Shaw \& Nodder, 1793), Turdus albicollis (Vieillot, 1818) and Coereba flaveola (Linnaeus, 1758) were classified as native-forest specialists.

In spite of the difference in species composition between eucalyptus plantations and the native forest, the results of the nestedness analysis showed that the bird species composition occurred in a nested way. Analyzing treatments of each plantation age separately showed that species nestedness in relation to the native forest increased with the age of the eucalyptus plantations (Table 2). The same was observed for overall nestedness ( $\mathrm{NODF}=72.16, p=0.001$ ), i.e., the bird communities found in plantations of different ages were a subset of the community in the native forest. When the observed nestedness was compared with null models $1(\mathrm{t}=3.28, p=0.002)$ and $2(\mathrm{t}=3.07, p=0.008)$, this pattern was maintained.

\section{Discussion}

The native forest showed higher richness and abundance, and a different bird species composition compared to the eucalyptus plantations of different ages. These results demonstrate that the changes in the bird species community were associated with forest replacement by commercial plantations. We can infer that the plantations acted as an environmental filter determining the occurrence of the species (Gomez et al., 2010). The lower richness, abundance and different bird species composition observed in the eucalyptus plantations in this study seem to reflect an overall pattern
Table 2. Nestedness analysis with pairwise comparisons between the four treatments and overall nestedness, i.e., plantations up to 3 years old (T1), plantations from 3 to 7 years (T2), plantations from 7 to 12 years (T3) and plantations from 14 to 25 years (T4) in relation to the native forest (NF).

\begin{tabular}{lcc}
\hline \multicolumn{1}{c}{ Treatments } & NODF & $\boldsymbol{p}$ \\
\hline T1 and NF & 75 & 0.003 \\
T2 and NF & 87.88 & 0.001 \\
T3 and NF & 90.32 & 0.001 \\
T4 and NF & 93.54 & 0.001 \\
Overall & 72.16 & 0.001 \\
\hline
\end{tabular}

that does not depend on the tree species used for plantation (Zurita et al., 2006; Barlow et al., 2007). This pattern of lower bird species richness in monocultures was also observed by Volpato et al. (2010) and Mendonça-Lima (2012) in pine plantations, and Motta-Junior (1990), Marsden et al. (2001) and Barlow et al. (2007) in eucalyptus plantations. This occurs because silviculture areas increase habitat similarity (Marsden et al., 2001; Filloy et al., 2010), supply fewer resources such as appropriate substrates for nesting and foraging, and thus similar bird communities are expected (Motta-Junior, 1990; Kwok and Corlett, 2000). Furthermore, the understory is less developed than in native forests, resulting in loss of habitat for many species (Fischer et al., 2006; Barlow et al., 2007).

The PCoA indicated the associations of individual species with the environments, highlighting three main groups. In plantations up to three years old, bird species typical of more open habitats predominated, for example 
Crotophaga ani (Linnaeus, 1758) and Ammodramus humeralis (Bosc, 1792). The second group united species recorded in older plantations, and was formed by species that show some dependence on the forest. The third group united species that were associated with native forest. This indicates a gradual replacement of bird species between plantations of different ages, and the forest. This replacement is due to structural changes between plantations, especially when they acquire some attributes of the forest, e.g., understory development.

The bird species classification showed that only a small number of species were associated with the eucalyptus plantations and with the native forest, whereas habitat generalists predominated. According to Fischer et al. (2006), generalist species tend to be more abundant in altered habitats. In addition, Willis (2003) suggested that the abundance of invasive plants is attractive to some generalist bird species. In a similar study conducted in southern Brazilian grasslands, Dias et al. (2013) also found that generalist birds were the predominant group. Volpato et al. (2010) recorded fewer forest-dependent bird species in eucalyptus plantations than in a native forest. Taken together, these studies show that species with a high degree of habitat specificity are harmed by silviculture, and are more susceptible to extinction (Marsden et al., 2001; Barlow et al., 2007). On the other hand, well-preserved forests have more-complex vegetation, which positively influences the richness and abundance of forest-dependent species (Gabriel, 2009).

The predominance of generalist species determined the distribution of nestedness, since these species are more tolerant and are able to inhabit eucalyptus plantations (Mendonça-Lima, 2012). In this study, the nestedness was directly related to the age of the plantations; in other words, a larger subset of the native forest species was found in the older plantations. This suggests that plantations that were established a long time ago are also more likely to be valuable habitat for a biodiverse fauna in general (Brockerhoff et al., 2008). On the other hand, species that use plantations up to three years old are the most harmed by silviculture, as also observed by Dias et al. (2013). In a study with nine taxonomic groups, including birds, Louzada et al. (2010) found a high level of nestedness for species of these groups between eucalyptus plantations, and primary and secondary forests. According to Mendonça-Lima (2012) the loss or replacement of species in silviculture areas seem to determine nestedness. Feeley et al. (2007) explained the occurrence of nestedness by selective loss of species, i.e., only species with fewer habitat requirements are able to "transpose" the conditions imposed by silviculture. Furthermore, other processes such as local immigration and species extinction may result in nestedness (Ulrich et al., 2009). These processes probably occur in the study area, as not all species from the native forest are able to colonize the plantations.

The results showed that plantations are functional habitats for a subset of local native forest species serve as a main or occasional habitat. This is determined by the tolerance of each species to the alterations imposed by silviculture. Because each species uses the plantations differently, with some, such as P. sulphuratus, even nesting (pers. obs.), others simply forage or use the plantations only as a corridor between other environments. With the growth of silviculture, it becomes essential to increase the utility of tree plantations as habitat for a more-diverse fauna. Thus, new forestation programs need to consider the matrix quality and connectivity between natural landscape elements, with the use of corridors and stepping stones, since many bird species recorded in monocultures use these sites as they move among areas (Fonseca et al., 2009). The adoption of these practices is key for the conservation of forest-dependent bird species, such as understory insectivores and large frugivores.

\section{Acknowledgements}

We thank CMPC Celulose Riograndense for financial and logistical support. We are grateful to Elias Araújo, who provided information about the study area, and to Rodrigo Didio dos Santos, Camila Saturno and Camila Bauchpiess who helped in the field work. We also thank PhD. Luiz dos Anjos, Rafael Dias, Jan Karel Félix Mähler and MSc. Eliane Regina da Silva for their valuable suggestions on the final version of the manuscript. SMH holds a research grant from the Conselho Nacional de Desenvolvimento Científico e Tecnológico (CNPq), process 306816/ 2010-5. LIJ received a scholarship from CNPq.

\section{References}

ALMEIDA-NETO, M. and ULRICH, W., 2011. A straightforward computational approach for measuring nestedness using quantitative matrices. Environmental Modelling \& Software, vol. 26, no. 2, pp. 173-178. http://dx.doi.org/10.1016/j.envsoft.2010.08.003.

ANJOS, L., COLLINS, C.D., HOLT, R.D., VOLPATO, G.V., MENDONÇA, L.B., LOPES, E.V., BOÇON, R., BISHEIMER, M.B., SERAFINI, P.P. and CARVALHO, J., 2011. Bird species abundance - occupancy patterns and sensitivity to forest fragmentation: implications for conservation in the Brazilian Atlantic forest. Biological Conservation, vol. 144, no. 9, pp. 2213-2222. http://dx.doi.org/10.1016/j.biocon.2011.05.013.

BARLOW, J., MESTRE, L.A.M., GARDNER, T.A. and PERES, C.A., 2007. The value of primary, secondary and plantation forests for Amazonian birds. Biological Conservation, vol. 36, no. 2, pp. 212-231. http://dx.doi.org/10.1016/j.biocon.2006.11.021.

BROCKERHOFF, E.G., JACTEL, H., PARROTTA, J.A., QUINE, C.P. and SAYER, J., 2008. Plantation forests and biodiversity: oxymoron or opportunity? Biodiversity and Conservation, vol. 17, no. 5, pp. 925-951. http://dx.doi.org/10.1007/s10531-008-9380-x.

CHAO, A. and LIN, S.Y., 2011 [viewed 15 June 2013]. Program CLAM (Classification Method) [online]. Available from: http:// chao.stat.nthu.edu.tw/wordpress/software_download/

CHAZDON, R.L., CHAO, A., COLWELL, R.K., LIN, S.Y., NORDEN, N., LETCHER, S.G., CLARK, D.B., FINEGAN, B. and ARROYO, J.P., 2011. A novel statistical method for classifying 
habitat generalists and specialists. Ecology, vol. 92, no. 6, pp. 1332-1343. http://dx.doi.org/10.1890/10-1345.1. PMid:21797161.

COLLES, A., LIOW, L.H. and PRINZING, A., 2009. Are specialists at risk under environmental change? Neoecological, paleoecological and phylogenetic approaches. Ecology Letters, vol. 12, no. 8, pp. 849-863. http://dx.doi.org/10.1111/j.14610248.2009.01336.x. PMid:19580588.

DECONCHAT, M., BROCKERHOFF, E.G. and BARBARO, L., 2009. Effects of surrounding landscape composition on the conservation value of native and exotic habitats for native forest birds. Forest Ecology and Management, vol. 285, pp. 196-204. http://dx.doi.org/10.1016/j.foreco.2009.08.003.

DIAS, R.A., BASTAZINI, V.A.G., GONÇALVES, M.S.S., BONOW, F.C. and MÜLLER, S.C., 2013. Shifts in composition of avian communities related to temperate-grassland afforestation in southeastern South America. Iheringia. Série Zoologia, vol. 103, no. 1, pp. 12-19.

FARWIG, N., SAJITA, N. and BÖHNING-GAESE, K., 2008. Conservation value of forest plantations for bird communities in western Kenya. Forest Ecology and Management, vol. 255, no. 11, pp. 3885-3892. http://dx.doi.org/10.1016/j.foreco.2008.03.042.

FEELEY, K.J., GILLESPIE, T.W., LEBBIN, D.J. and WALTER, H.S., 2007. Species characteristics associated with extinction vulnerability and nestedness rankings of birds in tropical forest fragments. Animal Conservation, vol. 10, no. 4, pp. 493-501. http://dx.doi.org/10.1111/j.1469-1795.2007.00140.x.

FILLOY, J., ZURITA, G.A., CORBELLI, J.M. and BELLOCQ, M.I., 2010. On the similarity among bird communities: Testing the influence of distance and land use. Acta Oecologica, vol. 36, no. 3, pp. 333-338. http://dx.doi.org/10.1016/j.actao.2010.02.007.

FISCHER, J., LINDENMAYER, D.B. and MANNING, A.D., 2006. Biodiversity, ecosystem function, and resilience: ten guiding principles for commodity production landscapes. Frontiers in Ecology and the Environment, vol. 2, no. 2, pp. 80-86. http:// dx.doi.org/10.1890/1540-9295(2006)004[0080:BEFART]2.0.CO;2.

FONSECA, C.R., GANADE, G., BALDISSERA, R., BECKER, C.G., BOELTER, C.R., BRESCOVIT, A.D., CAMPOS, L.M., FLECK, T., FONSECA, V.S., HARTZ, S.M., JONER, F., KÄFFER, M.I., LEAL-ZANCHET, A.M., MARCELLI, M.P., MESQUITA, A.S., MONDIN, C.A., PAZ, C.P., PETRY, M.V., PIOVENSAN, F.N., PUTZKE, J., STRANZ, A., VERGARA, M. and VIEIRA, E.M., 2009. Towards an ecologically-sustainable forestry in the Atlantic Forest. Biological Conservation, vol. 142, no. 6, pp. 1209-1219. http://dx.doi.org/10.1016/j.biocon.2009.02.017.

FOOD AND AGRICULTURE ORGANIZATION OF THE UNITED NATIONS - FAO, 2012 [viewed 16 August 2013]. Planted Forests [online]. Geneva: FAO. Available from: http:// www.fao.org/forestry/plantedforests/en/

GABRIEL, V.A., 2009. Comunidade de aves em um mosaico de Eucalyptus em Rio Claro, São Paulo. Rio Claro: Universidade Estadual Paulista Júlio de Mesquita Filho, 124 p. Tese de Doutorado em Ciências Biológicas.

GÓMEZ, J.P., BRAVO, G.A., BRUMFIELD, R.T., TELLO, J.G. and CADENA, C.D., 2010. A phylogenetic approach to disentangling the role of competition and habitat filtering in community assembly of Neotropical forest birds. Journal of Animal Ecology, vol. 79, no. 6, pp. 1181-1192. http://dx.doi. org/10.1111/j.1365-2656.2010.01725.x. PMid:20642767.
GOTELLI, N.J. and COLWELL, R.K., 2001. Quantifying biodiversity: procedures and pitfalls in the measurement and comparison of species richness. Ecology Letters, vol. 4, no. 4, pp. 379-391. http://dx.doi.org/10.1046/j.1461-0248.2001.00230.x.

HAMMER, Ø., HARPER, D.A.T., and RYAN, P.D., 2001. PAST: Paleontological Statistics software package for education and data analysis. Paleontological Electronic, vol. 4, pp. 01-09.

HOBBS, R., CATLING, P.C., WOMBEY, J.C., CLAYTON, M., ATKINS, L. and REID, A., 2003. Faunal use of bluegum (Eucalyptus globulus) plantations in southewestern Australia. Agroforestry Systems, vol. 58, no. 3, pp. 195-212. http://dx.doi. org/10.1023/A:1026073906512.

KWOK, H.K. and CORLETT, R.T., 2000. The bird communities of a natural secondary forest and a Lophostemon confertus plantation in Hong Kong, South China. Forest Ecology and Management, vol. 130, no. 1-3, pp. 227-234. http://dx.doi.org/10.1016/S03781127(99)00178-4.

LAMBECK, R.J., 1997. Focal species: a multi-species umbrella for nature conservation. Conservation Biology, vol. 11, no. 4, pp. 849-856. http://dx.doi.org/10.1046/j.1523-1739.1997.96319.x.

LEITE, P.F., 2002. Contribuição ao conhecimento fitoecológico do sul do Brasil. Ciência Ambiental, vol. 24, pp. 51-73.

LINDENMAYER, D.B., MCINTYREB, S. and FISCHER, J., 2003. Birds in eucalypt and pine forests: landscape alteration and its implications for research models of faunal habitat use. Biological Conservation, vol. 119, no. 1, pp. 45-53. http://dx.doi. org/10.1016/S0006-3207(02)00174-X.

LOUZADA, J., GARDNER, T., PERES, C. and BARLOW, J., 2010. A multi-taxa assessment of nestedness patterns across a multiple-use Amazonian forest landscape. Biological Conservation, vol. 143, no. 5, pp. 1102-1109. http://dx.doi.org/10.1016/j. biocon.2010.02.003

MARSDEN, S.J., WHIFFIN, M. and GALETTI, M., 2001. Bird diversity and abundance in forest fragments and Eucalyptus plantations around an Atlantic forest reserve, Brazil. Biodiversity and Conservation, vol. 10, no. 5, pp. 737-751. http://dx.doi. org/10.1023/A:1016669118956.

MENDONÇA-LIMA, A., 2012. Estrutura de habitat, diversidade e comportamento da avifauna em sistemas de silvicultura em Floresta Ombrófila Mista. Porto Alegre: Universidade Federal do Rio Grande do Sul, 149 p. Tese de Doutorado em Ciências.

MORENO, J.A. 1961. Clima Do Rio Grande do Sul. Porto Alegre: Secretaria da Agricultura. $41 \mathrm{p}$.

MOTTA-JUNIOR, J.C., 1990. Estrutura trófica e composição de avifaunas de três habitats terrestres na região central do estado de São Paulo. Ararajuba, vol. 1, pp. 65-71.

PATTERSON, B., 1990. On the temporal development of nested subset patterns species composition. Oikos, vol. 59, no. 3, pp. 330-342. http://dx.doi.org/10.2307/3545143.

PATTERSON, B.D. and ATMAR, W., 1986. Nested subsets and the structure of insular mammalian faunas and archipelagos. Biological Journal of the Linnean Society. Linnean Society of London, vol. 28, no. 1-2, pp. 65-82. http://dx.doi.org/10.1111/j.1095-8312.1986. tb01749.x.

PIACENTINI, V.Q., ALEIXO, A., AGNE, C.A., MAURÍCIO, G.N., PACHECO, J.F., BRAVO, G.A., BRITO, G.R.R., NAKA, L.N., OLMOS, F., POSSO, S., SILVEIRA, L.F., BETINI, G.S., CARRANO, E., FRANZ, I., LEES, A.L., LIMA, L.M., PIOLI, D., 
SCHUNCK, F., AMARAL, F.R., BENCKE, G.A., COHN-HAFT, M., FIGUEIREDO, L.F.A., STRAUBE, F.C. and CESARI, E., 2015. Annotated checklist of the birds of Brazil by the Brazilian Ornithological Records Committee. Revista Brasileira de Ornitologia, vol. 23, no. 2, pp. 91-298.

PILLAR, V.D., 2006 [viewed 10 March 2013]. MULTIV: Multivariate exploratory analisys, randomizating testing and boostraping resampling: users guide v. 2. 4. [online] Porto Alegre: UFRGS. Available from: http://ecoqua.ecologia.ufrgs.br/arquivos/ Software/Multiv/MultivManual.pdf

PILLAR, V.D. and ORLÓCI, L., 1996. On randomization testing in vegetation science: multifactor comparisons of relevé groups. Journal of Vegetation Science, vol. 7, no. 4, pp. 585-592. http:// dx.doi.org/10.2307/3236308.

R DEVELOPMENT CORE TEAM, 2012 [viewed 10 March 2013]. R: a language and environment for statistical computing [online]. Vienna: R Foundation for Statistical Computing. Available from: http://www.R-project.org/

SCHNECK, F., SCHWARZBOLD, A. and MELO, A.S., 2011. Substrate roughness affects stream benthic algal diversity, assemblage composition, and nestedness. Journal of the North American Benthological Society, vol. 30, no. 4, pp. 1049-1056. http://dx.doi.org/10.1899/11-044.1.

SEKERCIOGLU, C.H., DAILY, G.C. and EHRLICH, P.R., 2004. Ecosystem consequences of bird declines. Proceedings of the National Academy of Sciences of the United States of America, vol. 101, no. 52, pp. 18042-18047. http://dx.doi.org/10.1073/ pnas.0408049101. PMid:15601765.
SYDOW, V.G., 2010. Vegetação de sub-bosque em monocultura de Eucalyptus saligna Sm. (Myrtaceae). Porto Alegre: Universidade Federal do Rio Grande do Sul, 76 p. Dissertação de Mestrado em Ecologia.

ULRICH, W., ALMEIDA-NETO, M. and GOTELLI, N.J., 2009. A consumer's guide to nestedness analysis. Oikos, vol. 118, no. 1, pp. 3-17. http://dx.doi.org/10.1111/j.1600-0706.2008.17053.x.

VOLPATO, G.H., PRADO, V.M. and ANJOS, L., 2010. What can tree plantations do for forest birds in fragmented forest landscapes? A case study in southern Brazil. Forest Ecology and Management, vol. 260, no. 7, pp. 1156-1163. http://dx.doi. org/10.1016/j.foreco.2010.07.006.

WILLIS, E.O., 2003. Birds of a eucalyptus woodlot in interior São Paulo. Brazilian Journal of Biology $=$ Revista Brasileira de Biologia, vol. 63, no. 1, pp. 141-158. http://dx.doi.org/10.1590/ S1519-69842003000100019. PMid:12914426.

WRIGHT, D.H., PATTERSON, B.D., MIKKELSON, G.M., CUTLER, A. and ATMAR, W., 1998. A comparative analysis of nested subset patterns of species composition. Oecologia, vol. 113, no. 1, pp. 1-20. http://dx.doi.org/10.1007/s004420050348.

ZURITA, G.A., REY, N., VARELA, D.M., VILLAGRA, M. and BELLOCQ, M.I., 2006. Conversion of the Atlantic Forest into native and exotic tree plantations: Effects on bird communities from the local and regional perspectives. Forest Ecology and Management, vol. 235, no. 1-3, pp. 164-173. http://dx.doi. org/10.1016/j.foreco.2006.08.009. 